\title{
АНАЛІТИЧНИЙ ОГЛЯД ОНОВЛЕНИХ ОЦНОК ЩОДО ПЕРСПЕКТИВ РОЗВИТКУ ВІТРОЕНЕРГЕТИКИ
}

\begin{abstract}
С.О. Кудря, чл.-кор. НАН України, докт. техн. наук, проф., Б.Г. Тучинський, канд. екон. наук, ст. наук. співроб.,
\end{abstract} І.В. Іванченко

Інститут відновлюваної енергетики НАН України, 02094, вул. Гната Хоткевича, 20А, м. Київ.

Мета статті - визначення сучасних тенденцій і перспектив розвитку вітроенергетики. Дослідження виконано шиляхом аналізу статистичних даних і прогнозних оцінок, опублікованих в звітах високопрофесійних міжнародних організацій Міжнародного енергетичного агентства (IEA), Міжнародного агентства з відновлюваної енергетики (IRENA) $i$ Свропейської вітроенергетичної асочіачіï (EWEA), американської Національної лабораторії відновлюваної енергетики (NREL). Ці об'єктивні дані свідчать про надвисокі темпи розвитку вітроенергетики в країнах СС. За прогнозом, в Свросоюзі виробниичтво електроенергї ВЕС перевищить виробництво електроенергї ТЕС на вугіллі - в 2020 р., ГЕС - в 2025 р., АЕС - в 2028 p., ТЕС на газі - в 2035 р. Представлено нові уточнені оцінки вітропотенціалу Украйни. Виходячи з розподілу швидкостей вітру і територіальних обмежень, в Україні можливо створити економічно ефективних ВЕС: оншорних - потужністю 320 ГВт і офшорних мілководних - потужністю 146 ГВт. Загальний потенціал річного виробітку електроенергії цих ВЕС становить близько 1.5 млн ГВтггод, щз майже в 10 раз перевищує поточне річне спожсиваня. Украӥнська держава має зобов 'язання перед міжнародною спільнотою щудо переходу до низьковуглеиевої енергетики і, з ијєю метою, прискорення розвитку відновлюваної енергетики. Класифіковано вигоди розвитку вітроенергетики для українського суспільства. Виявлено, що Украйна, маючи найкращі умови для розвитку вітроенергетики і найвищі вигоди від цього, планує найнижчі в південно-східній Європі показники цього прочесу. Визначено роль украӥнської держави у прибиранні бар'єрів розвитку вітроенергетики і виведенні ї̈ на європейську траєкторію. Бібл. 6, табл. 2, рис. 1.

Ключові слова: технічно-досяжний вітропотенціал, електроенергетика, Свропа, Украӥна, вітрова електростанція, інвестииійна привабливість.

\section{ANALYTICAL REVIEW OF THE UPDATED ESTIMATES OF THE PROSPECTS FOR THE DEVELOPMENT OF WIND ENERGY}

S. Kudrya, Corresponding Member of NAS, Professor, Doctor of Technical Sciences, B. Tuchynskyi, Senior Researcher, Candidate of Economic Sciences, I. Ivanchenko

Institute of renewable energy, NAS Ukraine,

02094, 20A, Hnata Khotkevycha St., Kyiv.

Purpose of the article - the definition of current trends and prospects of wind power. The study conducted by analyzing the statistical data and forecast estimates published in the reports of highly professional international organizations - the International Energy Agency (IEA), the International Renewable Energy Agency (IRENA) and the European Wind Energy Association (EWEA), the American National Renewable Energy Laboratory (NREL). These objective data show extremely high rate of development of wind power in the EU. According to the forecast, the EU wind power electricity production exceeds electricity power station coal - in 2020, hydro - in 2025, nuclear power plants - in 2028, thermal power plants on gas - in 2035. Presents new refined estimates of wind potential in Ukraine. Based on the distribution of wind speeds and territorial restrictions in Ukraine may create a cost-effective wind farms, onshore - capacity of 320 $G W$, shallow offshore - a capacity of $146 \mathrm{GW}$. The total potential annual power generation of the wind farm is about 1.5 million GWh, which is almost 10 times higher than the current annual consumption. Ukrainian state has obligations to the international community to move towards low carbon energy and to this end accelerating the development of renewable energy. The benefits of wind energy for the Ukrainian society are classified. It revealed that Ukraine, having the best conditions for the development of wind energy and the highest benefits from it, plans the indicators of this process, the lowest in South Eastern Europe. The role of the Ukrainian state in the elimination of barriers to the development of wind energy and its derivation on the European trajectory is determined. Ref. 6, tabl. 2, fig. 1.

Keywords: technical wind potential, power, Europe, Ukraine, wind power, investment attractiveness. 

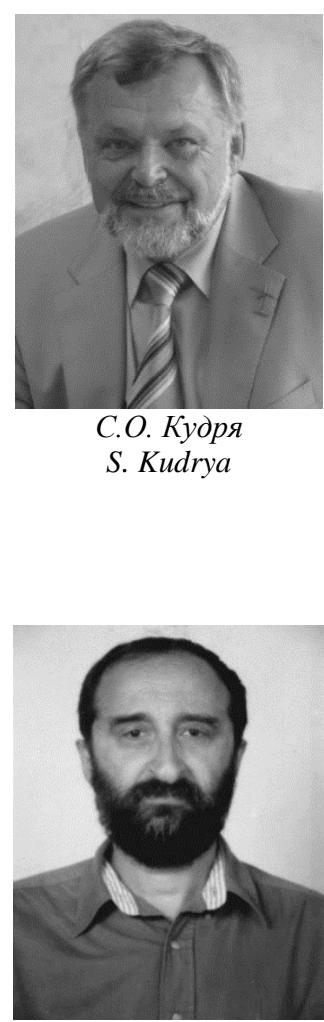

Б.Г. Тучинський B. Tuchynskyi

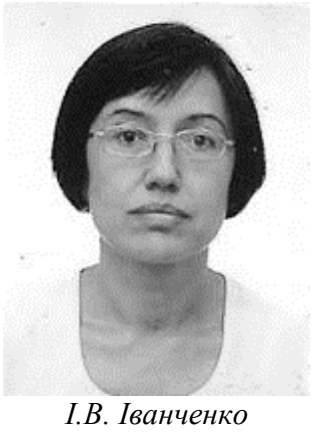

I. Ivanchenko
Відомості про автора: Директор Інституту відновлюваної енергетики НАН України, член-кореспондент НАН України, професор, доктор технічних наук.

Освіта: Національний технічний університет України «Київський політехнічний інститут ім. І. Сікорського», хіміко-технологічний факультет.

Наукова сфера: відновлювана енергетика, енергоефективні технології, комплексні енергетичні системи.

Публікації: 370.

ORCID: 0000-0002-4798-6853

Контакти:

тел./факс: +38 (044) 206-28-09

e-mail: renewable@ukr.net

Відомості про автора: старший науковий співробітник відділу вітроенергетики Інституту відновлюваної енергетики НАН України, старший науковий співробітник, кандидат економічних наук.

Освіта: Київський національний університет ім. Тараса Шевченка, механіко-математичний факультет.

Наукова сфера: прикладна математика, обчислювальні методи, математична статистика, математичні моделі і методи в економіці, інвестиційний аналіз, вітроенергетика.

Публікації: 117.

ORCID: 0000-0002-5180-6886

Контакти:

тел./факс: +38 (044) 206-28-09

e-mail: bortu77@yahoo.com

Відомості про автора: головний технолог відділу вітроенергетики Інституту відновлюваної енергетики НАН України.

Освіта: Київський національний університет технологій та дизайну, інженерноекономічний факультет.

Наукова сфера: вітроенергетика, оцінка вітроенергетичного потенціалу, економічна ефективність інвестицій в будівництво вітрових електростанцій.

Публікації: 28

ORCID: 0000-0002-5083-4180

Контакти:

тел./факс: +38 (044) 206-28-09

e-mail: mntcwind@gmail.com
Author information: Director of the Institute of Renewable Energy of NAS of Ukraine, Corresponding Member of NAS of Ukraine, Professor, Doctor of Technical Sciences.

Education: National Technical University of Ukraine "Igor Sikorsky Kyiv Polytechnic Institute", Faculty of Chemical Technology.

Research area: renewable energy, energy efficient technologies, hybrid renewable energy systems.

Publications: 370 .

ORCID: 0000-0002-4798-6853

Contacts:

tel./fax: +38 (044) 206-28-09

e-mail: renewable@ukr.net

Author information: Senior Researcher at wind energy department at Institute of Renewable Energy of NAS of Ukraine, Senior Researcher, Candidate of Economic Sciences.

Education: Taras Shevchenko National University of Kyiv, Faculty of Mechanics and Mathematics.

Research area: Applied Mathematics, Computational Methods in Mathematics, Mathematical Statistics, Mathematical Models and Methods in Economics, Investment Analysis, Wind Power.

Publications: 117.

ORCID: 0000-0002-5180-6886

Contacts:

tel./fax: +38 (044) 206-28-09

e-mail: bortu77@yahoo.com

Author information: chief technologist at wind energy department at Institute of Renewable Energy of NAS of Ukraine.

Education: Kiev National University of Technology and Design, Faculty of Engineering and Economics.

Research area: wind energy, assessment of wind energy potential, economic efficiency of investments in the construction of wind power plants.

Publications: 28

ORCID: 0000-0002-5083-4180

Contacts:

tel./fax: +38 (044) 206-28-09

e-mail: mntcwind@gmail.com

Перелік використаних позначень та скорочень:

$\mathrm{CC}-$ Свропейський Союз;

ВEC - вітрова електростанція;

ВЕУ - вітрова електроустановка;

TEC -теплова електростанція;

ГЕС - гідроелектростанція;
АЕС - атомна електростанція;

ТДВП - технічно-досяжний вітропотенціал;

GIS - геоінформаційна система;

КВВП - коефіцієнт використання встановленої потужності;

ГВТ -гігават;

НДР - науково-дослыдна робота.
Вступ. На початку XXI ст. в розвитку світової вітроенергетики відбулися радикальні зміни. Ця галузь стала першою з галузей відновлюваної енергетики, що увійшла до складу “великої” електроенергетики. Сьогодні європейська вітроенергетика генерує більш, ніж
$10 \%$ споживаної в Європі електроенергії. Рівень $20 \%$ споживання електроенергії перевищили Данія, Іспанія, Португалія, Ірландія. На сьогодні вітроенергетика $\epsilon$, і буде в перспективі, найбільш привабливою для інвесторів галуззю європейської електроенергетики. Так, за 
прогнозом авторитетного Міжнародного енергетичного агентства (IEA) [1], в СС сума інвестицій у вітроенергетику в період 2014-2035 рр. становитиме 727 \$млрд і буде найвищою серед галузей електроенергетики - в 1.8 рази вищою, ніж в атомну і теплову разом. На рис. 1 подано дані щодо сучасного стану і прогнозу показників річного виробітку електроенергії в Європі для вітроенергетики і всіх традиційних технологій генерації (підготовлено відомою міжнародною фаховою компанією DNV GL для $\epsilon_{\text {в- }}$ ропейської вітроенергетичної асоціації).

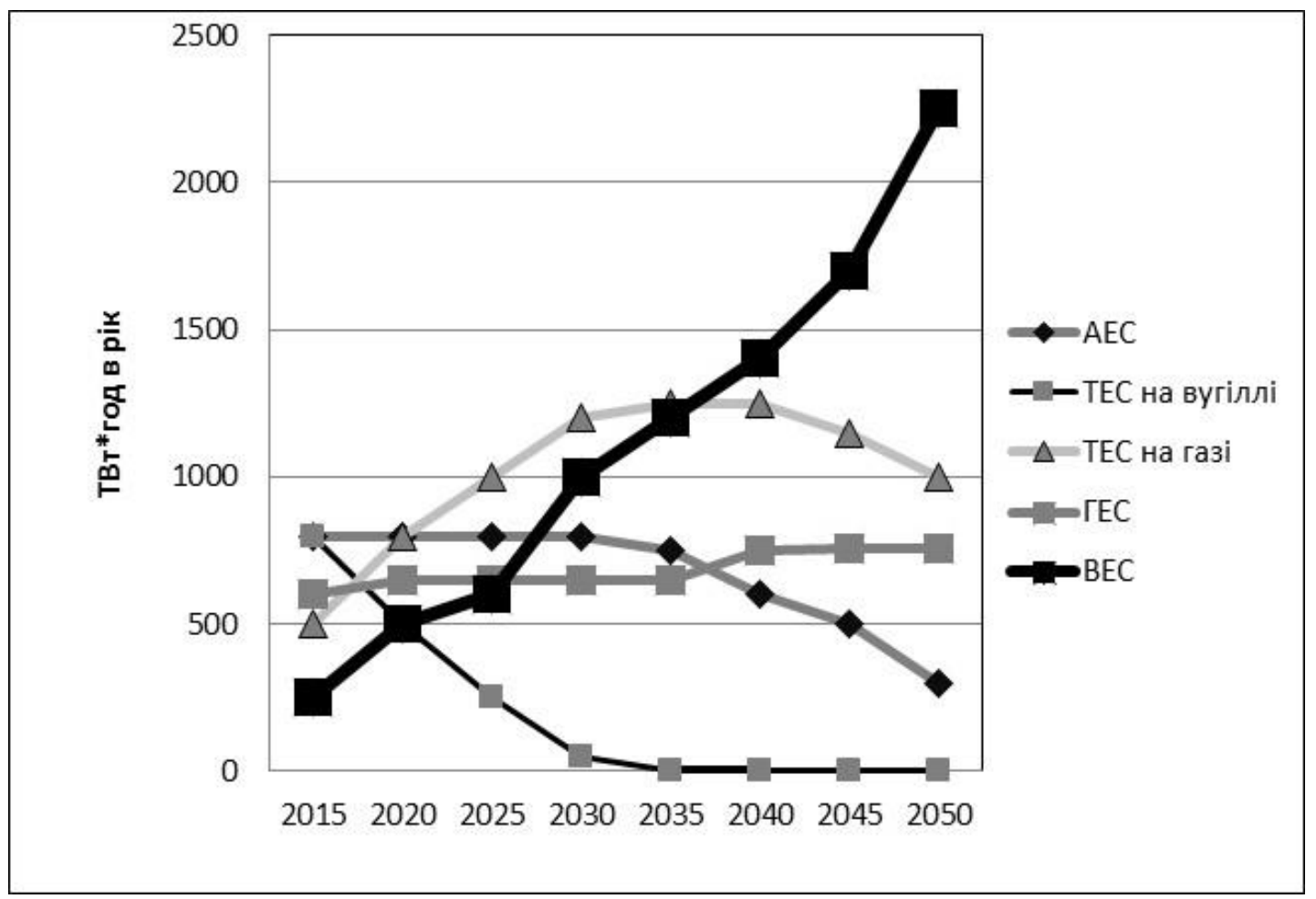

Рис. 1. Прогноз річного виробітку електроенергії в Свропі.

Fig. 1. Forecast of annual power generation in Europe.

3 рис. 1 випливає, що в країнах $\mathrm{CC}$ виробництво електроенергії ВЕС перевищить виробництво електроенергії: ТЕС на вугіллі - в 2020 р., ГЕС - в 2025 p., AEC - в 2028 р., TEC на газі - в $2035 \mathrm{p}$.

Різке зростання масштабів і темпів розвитку вітроенергетики стало можливим завдяки розширенню і поглибленню науково-дослідних робіт (НДР). Табл. 1, яка сформована за даними 3 [2], демонструє значні масштаби фінансування НДР для цілей вітроенергетики (в млрд. доларів США) на всіх континентах.

Таблиця 1. Передбачені суми інвестицій в НДР для вітроенергетики до 2026 року.

Table 1. Expected amounts R\&D Investment for wind power by 2026.

\begin{tabular}{|l|r|r|}
\hline \multicolumn{1}{|c|}{ Континент } & Інвестиції в НДР для вітроенергетики, \$млрд & Частка, \% \\
\hline Свропа & 12.9 & 34.77 \\
\hline Північна Америка & 9.3 & 25.07 \\
\hline Південна Америка & 1.9 & 5.12 \\
\hline Азія & 11.1 & 29.92 \\
\hline Африка & 1.1 & 2.96 \\
\hline Австралія & 0.8 & 2.16 \\
\hline Разом & $\mathbf{3 7 . 1}$ & $\mathbf{1 0 0 . 0 0}$ \\
\hline
\end{tabular}


Постановка задачі. У зв'язку зі значною масштабністю інвестування виникла необхідність уточнення оцінок максимальної сумарної потужності технічно можливих і економічно ефективних ВEC, створених на території кожної країни. Така оцінка називається технічно-досяжним вітропотенціалом (ТДВП). В 1990-2005 рр. відповідні дослідження ТДВП України здійснювались авторитетними закордонними організаціями (INFORSE, EBRD, OECD, IRENA) і компаніями (BLACK\&VEATCH， 3TIER). Отримані оцінки для “дослідженого” вітропотенціалу становили 14-24 ГВт. Методики оцінювання не публікувались. Скоріше за все застосовувались методи експертного оцінювання разом з аналізом фондових даних щодо швидкостей вітру. Також відсутня інформація щодо валідації використаних даних і точності розрахунків.

Аналітичний огляд. В 2009 р. Європейське агентство 3 охорони довкілля (ЕEA) розробило удосконалену методику оцінювання ТДВП [3]. Для iї реалізації використовуються сучасні засоби, зокрема: GIS, бази даних характеристик вітру (в тому числі - дані реаналізу), бази даних технічних параметрів ВЕУ. Ці засоби дозволяють значно розширити територію “дослідженого” ТДВП і зробити отримані оцінки більш обгрунтованими.

Дана методика полягає в здійсненні наступних кроків:

1. Виключення територій, не придатних апріорно для будівництва ВEC, а саме: урбанізованих місцевостей, лісів, водних об'єктів, автомобільних і залізничних шляхів, трубопроводів, природоохоронних та культивованих територій, пам'яток культури тощо.

2. Оцінювання для площадок, що залишились, КВВП вибраних моделей ВЕУ і вилучення територій, для яких отримані оцінки менші наперед заданого критичного значення.

3. Визначення шляхом проектних розрахунків і аналізу статистичних даних діючих ВЕС оцінки середньої щільності розміщення ВЕУ на площадці.

4. Виконання розрахунку потенціальної потужності BEC на території регіону.

Методику [3] використано в [4] для отримання нових уточнених оцінок вітропотенціалу країн південно-східної Європи (табл. 2).

Таблиця 2. Показники прогнозу розвитку вітроенергетики країн південно-східної Свропи.

Table 2. Indicators for the forecast of wind energy development in South East Europe.

\begin{tabular}{|c|c|c|c|c|}
\hline $\begin{array}{c}\text { Країна Південно-Східної } \\
\text { Свропи }\end{array}$ & КВВП & $\begin{array}{c}\text { Річний виробі- } \\
\text { ток електро- } \\
\text { енергї̈ ВЕС, } \\
\text { ГВт·год } \\
\end{array}$ & $\begin{array}{c}\text { Річний виробіток } \\
\text { електроенергії ВЕС } \\
\text { на душу населення, } \\
\text { ГВт·год } \\
\end{array}$ & $\begin{array}{c}\text { Зобов'язання країн за На- } \\
\text { цпланами, } \\
\text { \% від споживання }\end{array}$ \\
\hline & \multicolumn{3}{|c|}{ Потенціал } & \\
\hline Албанія & 0.20 & 13654 & 0.0045 & 3.5 \\
\hline Боснія та Герцеговина & 0.23 & 26336 & 0.0068 & 2.9 \\
\hline Болгарія & 0.20 & 52851 & 0.0076 & 4.9 \\
\hline Хорватія & 0.22 & 29153 & 0.0065 & 3.0 \\
\hline Косово & 0.19 & 3850 & 0.0021 & 7.8 \\
\hline Чорногорія & 0.25 & 6481 & 0.0010 & 5.3 \\
\hline Молдова & 0.27 & 50236 & 0.0140 & 6.4 \\
\hline Румунія & 0.21 & 154034 & 0.0071 & 5.5 \\
\hline Сербія & 0.20 & 52386 & 0.0058 & 1.9 \\
\hline Словенія & 0.18 & 2296 & 0.0012 & 8.3 \\
\hline Македонія & 0.18 & 7655 & 0.0037 & 8.0 \\
\hline Украӥна & 0.31 & 858452 & 0.0190 & 0.7 \\
\hline
\end{tabular}


Аналіз даних, наведених в табл. 2 дозволяє зробити наступні висновки:

1. Природа забезпечила Україні наявність дуже високого ТДВП. На доступних територіях середній КВВП=0.31 потенціальних українських BEC перевищує відповідний середній показник для інших країн південно-східної Свропи на $48 \%$. Це означає, що встановивши одну й ту саму модель ВЕУ в Україні, інвестор отримає в середньому майже в півтора рази більше електроенергії, ніж в південно-східній Європі. Ще більшим буде відповідний приріст виручки від продажу електроенергії (враховуючи, що в Україні “зелений” тариф на електроенергію ВЕС перевищує середній по південно-східній Свропі).

2. Важливим позитивним природним фактором для розвитку вітроенергетики України є "географічна дисперсія" вітропотенціалу - наявність площадок для ВЕС практично на всій території України. Це дозволяс оптимізувати підключення кожної ВЕС до електромережі, полегшити балансування роботи енергосистеми в умовах переривчастості генерації електроенергії ВЕС.

3. Загальна досяжна встановлена потужність наземних ВЕС в Україні оцінюється в 320 ГВт [4]. Всі ці ВЕС можуть виробляти щорічно в середньому біля 860 тис ГВт.год, що в п'ять раз перевищує споживання електроенергії в країні. У той же час, в силу розкиду ТДВП навколо середнього, існує висока ймовірність того, що в Україні можна вишукати значну кількість площадок для ВЕС з КВВП > 0.40. Такі високодохідні площадки будуть доступні тим інвесторам, які раніше інших наважаться інвестувати в будівництво ВЕС в Україні.

4. Звертаємо увагу, що вище йшлося лише про ТДВП оншорних (наземних) територій України. Але Україна має чудові можливості будувати ВЕС на мілководних територіях великих акваторій Азовського моря, заливу Сиваш, водосховищ Дніпровського каскаду ГЕС, лиманів. За даними дослідження Національної лабораторії відновлюваної енергетики NREL (США), площа мілководдя дозволяє побудувати в Україні офшорні ВЕС потужністю 146 ГВт, у яких середній КВВП на 50\% вищий, ніж у наземних [5]. Витрати ж на будівництво і експлуатацію офшорних ВЕС на мілководді несуттєво перевищують відповідні витрати для наземних BEC, що разом гарантує дуже високу доходність ВЕС. Потенціал річного виробітку електроенергії мілководних офшорних ВЕС України становить 640 тис ГВт.год. Загальний потенціал річного виробітку електроенергії ВЕС України становить близько 1.5 млн ГВт·год, що майже в 10 раз перевищує поточне річне споживання.
5. Додатковими природними зручностями для доставки великогабаритних ВЕУ на площадку ВEC є наявність в Україні морів і потужних морських портів, а також плоский рельєф майже всієї території країни.

6. Серед країн південно-східної Європи Україна має найвищий показник потенціального виробітку електроенергії ВЕС на душу населення (табл. 2).

Висновки. Всі перелічені переваги України, створені іï природою, вже оцінені інвесторами BEC. На сьогодні Україна є для них країною 3 найвищою економічною ефективністю інвестицій в ВEC. В той же час, Україна має найбільшу кількість бар'єрів і перешкод для реалізації інвестиційних проектів ВЕС, що чиняться з боку традиційної енергетики. Така ситуація мала місце в усіх країнах Європи. Але політичні, економічні, екологічні та інші переваги вітроенергетики мотивували органи державної влади цих країн прибрати всі ці перешкоди і забезпечити для вітроенергетики найвищі темпи росту.

Тепер слово за нашою державою. Наразі Україна має колосальні проблеми в електроенергетиці, а саме:

- терміни ефективної і безпечної експлуатації енергетичного обладнання АЕС і ТЕС суттєво перевищили проектні нормативи - зволікання 3 реновацією обладнання постійно підвищує ризики глобальних і локальних катастроф і робить функціонування електростанцій економічно i екологічно неефективним;

- українська традиційна електроенергетика $\epsilon$ суттєво залежною від імпорту: енергоносіїв урану і паливних елементів з РФ, газу і вугілля також значною мірою від РФ - країни, що у будьякий момент здатна всупереч договорам залишити нашу електроенергетику без енергоносіїв, а країну - без електроенергії;

- українська держава має зобов'язання перед міжнародною спільнотою щодо переходу до низьковуглецевої енергетики i, з цією метою, прискорення розвитку відновлюваної енергетики [6].

Модернізація української електроенергетики потребує великомасштабних інвестицій, які можуть бути залучені тільки з ринку капіталу. Сьогодні галуззю української електроенергетики, що має найвищу інвестиційну привабливість, $є$ вітроенергетика, яка має важливі переваги як для бізнесу, так і для суспільства, а саме:

- найнижчу собівартість електроенергії;

- найнижчі інвестиційні лаги;

- модульність енергетичного обладнання ВEC, що забезпечує можливість суттєвого збільшення дохідності відповідного інвестиційного 
проекту завдяки застосуванню інструменту реінвестування прибутку;

- забезпечує зменшення втрат електроенергії в процесі їі передачі на великі відстані від потужних TEC i AEC завдяки наближенню ВEC до споживачів електроенергії;

- забезпечує екологічну чистоту генерації електроенергіï та ін.

Безумовно, в силу перелічених обставин, українська держава раніше чи пізніше створить сприятливий інвестиційний клімат, і інвестори, побачивши тенденцію до зменшення ризиків, неодмінно вкладуть великі кошти в українську вітроенергетику і в короткі строки побудують потужні ВЕС. Свропейський досвід свідчить, що в країнах зі стабільною економікою реально протягом п'яти-шести років ввести в експлуатацію ВЕС загальною потужністю 30 ГВт.

1. World Energy Investment Outlook. Special Report. OECD/IEA. 2014. 190 p. [Електронний pecypc]. URL: https://www.iea.org/publications/freepublications/publication/W EIO2014.pdf.

2. Next gen wind technologies to get $\$ 36.9$ billion R\&D Investment by 2026. [Електронний pecypc]. URL: https://www.windpowerengineering.com/business-newsprojects/next-gen-wind-technologies-get-36-9-billion-rdinvestment-2026/.

3. Europe's onshore and offshore w0069nd energy potential. An assessment of environmental and economic constraints. EEA Technical report. 2009. № 6.90 p. [Електронний ресурс] URL: https://www.eea.europa.eu/publications/europes-onshoreand-offshore-wind-energy-potential.

4. Cost-competitive renewable power generation: Potential across South East Europe. IRENA. 2017. 124 p.

5. Improved Offshore Wind Resource Assessment in Global Climate Stabilization Scenarios. NREL. 2012. 29 p.

6. Кудря С.О., Тучинський Б.Г., Іванченко І.В. Вітроенергетика України - цілі, зобов'язання, результати і перспективи. Відновлювана енергетика та енергоефективність у XXI столітті. Матеріали XX міжнародної науково-практичної конференції. Київ. 2019. С. 408-414.

\section{REFERENCES}

World Energy Investment Outlook. Special Report OECD/IEA. 2014. 190 p. [Electronic resource]. URL: https://www.iea.org/publications/freepublications/publication/W EIO2014.pdf. [in English].

2. Next gen wind technologies to get $\$ 36.9$ billion $R \& D$ Investment by 2026. [Electronic resource]. URL: https://www.windpowerengineering.com/business-newsprojects/next-gen-wind-technologies-get-36-9-billion-rdinvestment-2026/. [in English].

3. Europe's onshore and offshore w0069nd energy potential. An assessment of environmental and economic constraints.
EEA Technical report. 2009. № 6. 90 p. [Electronic resource]. URL: https://www.eea.europa.eu/publications/europes-onshoreand-offshore-wind-energy-potential. [in English].

4. Cost-competitive renewable power generation: Potential across South East Europe. IRENA. 2017. 124 p. [in English].

5. Improved Offshore Wind Resource Assessment in Global Climate Stabilization Scenarios. NREL. 2012. 29 p. [in English].

6. Kudrya S.O., Tuchynskyj B.G., Ivanchenko I.V. Vitroenergetyka Ukrayiny - cili, zobovyazannya, rezultaty i perspektyvy. [Wind energy Ukraine - aims, liabilities, results and prospects]. Vidnovlyuvana energetyka ta energoefektyvnist u XXI stolitti. Materialy XX mizhnarodnoyi naukovo-praktychnoyi konferenciyi. Kyiv. 2019. Pp. 408-414. [in Ukrainian].

\section{АНАЛИТИЧЕСКИЙ ОБЗОР ОБНОВЛЕННЫХ ОЦЕНОК ПЕРСПЕКТИВ РАЗВИТИЯ ВЕТРОЭНЕРГЕТИКИ}

С.А. Кудря, чл.-кор. НАН Украины, докт. техн. наук, проф., Б.Г. Тучинский, канд. экон. наук, ст. науч. сотруд., И.В. Иванченко.

Институт возобновляемой энергетики НАН Украины 02094, ул. Г. Хоткевича, 20А, г. Киев.

Цель статьи - определение современных тенденций и перспектив развития ветроэнергетики. Исследование выполнено путем анализа статистических данных и прогнозных оценок, опубликованных в отчетах высокопрофессиональных международных организаций - Международного энергетического агентства (IEA), Международного агентства по возобновляемой энергетике (IRENA), Европейской ветроэнергетической ассоичиачии (ЕWEA), американской Национальной лаборатории возобновляемой энергетики (NREL). Эти объективные данные свидетельствуют о сверхвысоких темпах развития ветроэнергетики в странах ЕС. По прогнозу, в Евросоюзе производство электроэнергии ВЭС превысит производство электроэнергии ТЭС на угле - в 2020 г., ГЭС - в 2025 г., АЭС - в 2028 г., ТЭС на газе - в 2035 г. Представлены новые уточненные оченки ветропотенциала Украины. Исходя из распределения скоростей ветра и территориальных ограничений, в Украине возможно создать экономически эффективных ВЭС: оншорных - мощностью 320 ГВт и оффшорных мелководных - мощностью 146 ГВт. Общий потенцииал годовой выработки электроэнергии этих ВЭС составляет около 1.5 млн ГВт.ч, что почти в 10 раз превышает текущее годовое потребление. Украинское государство имеет обязательства перед международным сообществом по переходу к низкоуглеродной энергетике и, с этой иелью, ускорение развития возобновляемой энергетики. Классифицированы выгоды развития ветроэнергетики для украинского общества. Выявлено, что Украина, имея лучшие условия для развития ветроэнергетики и высокие выгоды от этого, планирует самые низкие в юго-восточной Европе показатели этого процесса. Определена роль украинского государства в удалении барьеров развития ветроэнергетики и выводе ее на европейскую траекторию. Библ. 6, табл. 2, рис. 1.

Ключевые слова: технически достижсимый ветропотенииал, электроэнергетика, Европа, Украина, ветровая электростанция, инвестиционная привлекательность. 